\title{
Fortællinger \\ om slægtskab i cancergenetisk rådgivning
}

\section{Af Mette Nordahl Svendsen}

\section{Tilborer gener individet eller}

familien? Hvad betyder det at vave genetisk forbundet?

Der bliver stillet skarpt på forstàelser af gener, krop og slegtskab, som de kommer til udtryk i forbindelse med cancergenetisk raidgivning og testning.

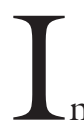

nden for de sidste årtier har forskning om menneskets gener været genstand for stor samfundsmæssig opmærksomhed. Med den ny genetik forventes, at en række folkesygdomme som for eksempel kræft, diabetes og Alzheimers både kan forklares, diagnosticeres, forebygges og behandles $i$ et større omfang end hidtil. På kræftområdet er der i Danmark inden for de sidste 5-10 år oprettet genetiske rådgivningsklinikker, hvor raske personer fra familier med mange kræfttilfælde kan få vurderet deres sygdomsrisiko og eventuelt blive gentestet med henblik på at finde ud af, om de bærer en genetisk disposition for at udvikle enten tyktarms- eller brystkræft. ${ }^{1}$ I denne kortlægning af genetiske sygdomsrisici skabes en kulturelt betinget sammenhæng mellem slægtskab og sygdom. Ved at tegne et stamtræ over hele den genetiske slægt, og på dette stamtræ anføre sygdomstilfælde for de enkelte personer, definerer rådgiveren en genetisk sammenhæng mellem individuelle sygdomstilfælde. ${ }^{2}$ Det be- 
tyder, at gener begrebsliggøres som forbindelseskæder mellem individer, mellem generationer, mellem grene af familier. Samtidig italesættes gener også - af både rådgivere og klienter - som tilhørende den enkelte og som lokaliseret i individet. Disse måder at forstå gener på bliver i de cancergenetiske rådgivningssamtaler udgangspunkt for forskellige kulturelle fortællinger om slægtskab. Spørgsmålene, som vil blive taget op i denne artikel, er, hvordan den ny genetik definerer relationer mellem individ og slægt, og hvordan forståelser af slægt relaterer sig til forståelser af krop og køn. ${ }^{3}$

\section{ET ANTROPOLOGISK PERSPEKTIV PÅ SLAGTSKAB}

Studiet af slægtskab hører til antropologiens kerneområder. I midten af 1900-tallet blev slægtskab regnet for det mest struktu- rerende forhold for social organisation i stort set alle samfund uden for Europa og USA. De mange forskellige slægtskabssystemer, som antropologer identificerede rundt omkring i verden, blev betragtet som forskellige socialt betingede måder at anerkende og forstå biologiske relationer på (Bouquet 1996, 47). Den amerikanske antropolog David Schneiders studie af amerikansk slægtskab (1968) er betydningsfuldt, fordi det på den ene side vokser ud af tanken om slægtskab som afgørende for social organisation, og på den anden side - ved at lade eget samfund være genstand for denne tilgang - synliggør, at den antropologiske slægtskabstilgang bygger på kulturelt betingede forestillinger om, at natur og biologi er fundament for sociale forhold (Carsten $2000,8)$. Netop den særlige måde at opfatte relationen mellem det naturlige og det sociale på i den vestlige verden er omdrej-

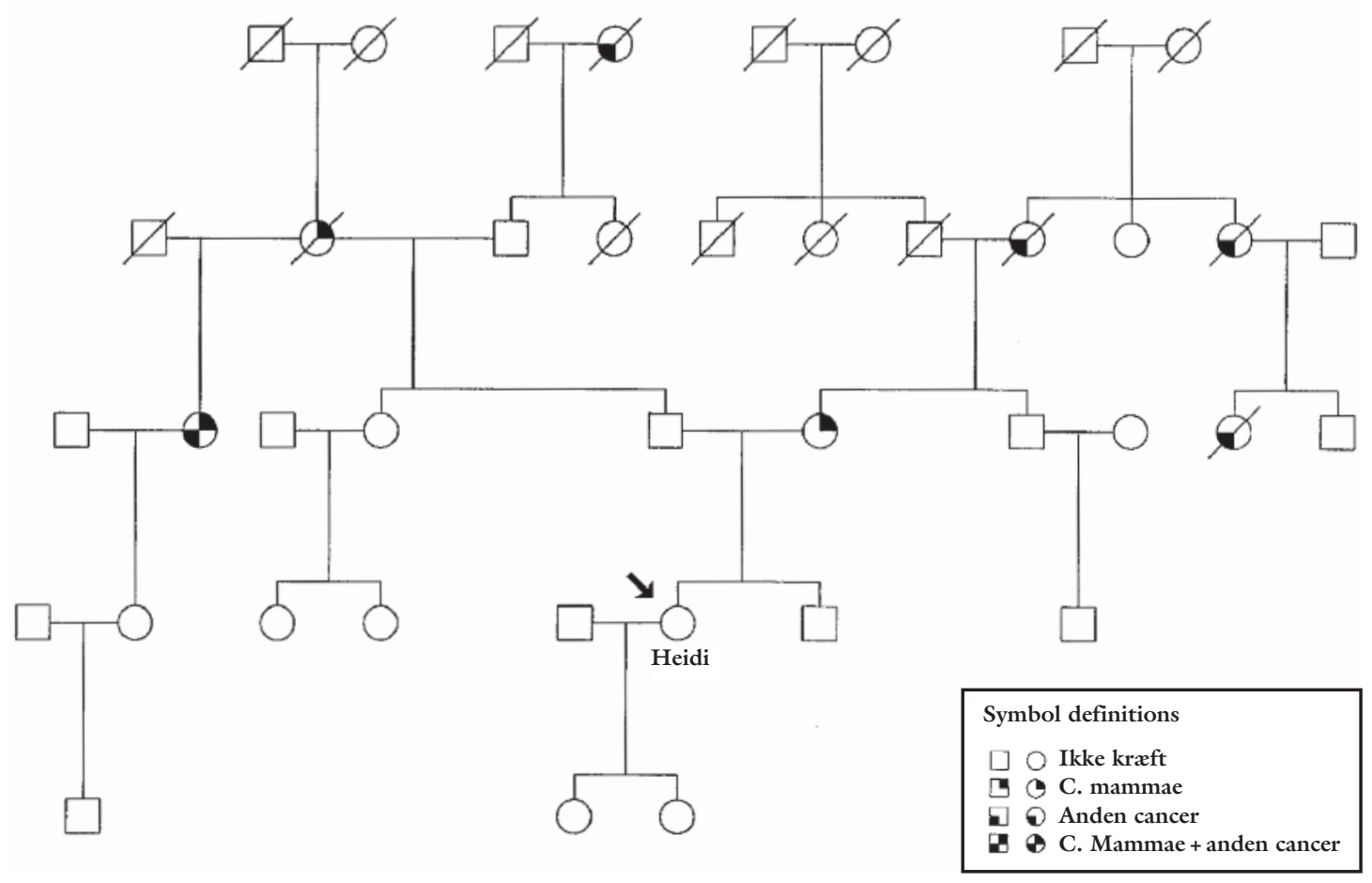

Udsnit af Heidis stamtre. Kilde: Cancergenetisk raidginningsklinik i Danmark. 
ningspunkt i de antropologiske studier af slægtskab i England, som udviklingen inden for reproduktions- og genteknologi har affødt (Strathern 1992a + b, Franklin 1997, Edwards 1999, Edwards \& Strathern 2000). Stratherns analyser af den offentlige debat om forplantningsteknologien viser, at det sociale - for eksempel forpligtende omsorgs/ansvarsrelationer i familien - forstås som en overbygning på, hvad der opfattes som naturlige facts. Samtidig viser både Stratherns, Edwards og Franklins studier, at reproduktions- og genteknologien udfordrer forståelsen af natur som adskilt fra det sociale, idet disse teknologier netop introducerer et valg og en social manipulation $i$ det, der hidtil blev betragtet som naturligt givet som for eksempel den reproduktive handling. Ovennævnte studier omhandler på den måde nye slægtskabspraksisser, der ekspliciterer kulturelle forståelser af slægtskab ved netop at anfægte dem (TjørnhøjThomsen 1999, 15).

Med afsæt i disse studier er min interesse i det følgende at analysere, hvordan forskellige kulturelle forståelser af slægtskab og dermed af relationen mellem 'det biologiske' og 'det sociale' kommer til udtryk i forbindelse med kortlægning af genetiske risici. Det empiriske udgangspunkt er en række observationer af cancergenetiske rådgivningssamtaler, i hvilke kliniske genetikere, i det følgende kaldt rådgivere, vurderer enkeltpersoners genetisk betingede risiko for kræft. To cases er valgt som udgangspunkt for diskussionen. Først følger en introduktion til det perspektiv på individ og slægt, som anlægges i den cancergenetiske rådgivning.

\section{FÆLLESSKABSKROPPEN:}

FORTÆLLINGER OM RISIKO OG SLÆGT

I min analyse af den cancergenetiske rådgivningssamtale anskuer jeg samtalen mellem rådgiver og klient ${ }^{4}$ som en igangværende dialogisk fortelling, ${ }^{5}$ hvor forskellige kulturelle forestillinger om slægtskab italesæt- tes. At fortællingen er dialogisk vil sige, at den konstrueres i dialog - i social interaktion - hvor dialogens parter (her klient og rådgiver) begge har indflydelse på forløb og indhold (Busch 1997, 14). Et sådant analytisk perspektiv er blandt andet udviklet af Cheryl Mattingly (1998), der argumenterer for, at erfaring og handling har en fortælleagtig karakter; det vil sige, at aktører i social interaktion skaber en fortælling om, hvor de er på vej hen, og hvad der er målet med det, som de er i gang med (Mattingly 1998, 69). For Mattingly betyder dette ikke, at social interaktion og erfaring dermed er forudbestemt og helstøbt som en fortælling. Hvad der især forbinder erfaring med fortælling, er det narrative drama, konflikten, hvor betydning forhandles og derfor hele tiden er under tilblivelse.

Fortællinger har $\mathrm{i}$ analytisk forstand en grundstruktur, som består af en begyndelse, en midte og en slutning i de tidslige dimensioner fortid, nutid, fremtid (Busch 1997, 14). Nuet anskues som udsprunget af en bestemt fortid og som pegende hen på en ønsket fremtid (Bruner 1986, 142). Fortællingens nutid får således betydning $\mathrm{i}$ kraft af at være et midlertidigt rum mellem en fortid og en ønsket fremtid (Mattingly 1998, 93). Enhver fortælling har et plot. Plottet tilfører fortællingen en form og et perspektiv, som knytter fortællingens handlinger og hændelser sammen til et hele og dermed giver fortællingen mening (Mattingly 1998, 46).

Den genetiske rådgivnings overordnede fortælling består af en fortid med sygdom i familien, en nutid hvor sygdommens årsag kortlægges og en risikovurdering nås (risikoudredning) og en fremtid med handlinger, der skal hindre sygdom i at opstå (risikohåndtering). Denne fortælling orienterer sig mod og har bekxmpelsen af potentiel sygdom som sit hovedplot. En diskussion af forskellige måder at kontrollere risikoen på hører med til enhver rådgivning, og det er almindeligt, at personer med en forhøjet risiko tilmeldes jævnlige kontrolundersøgel- 
ser med sigte på at opspore mulig fremtidig sygdom på et tidligt stadium. ${ }^{6}$

Det sygdomsforebyggende rationale udgør en implicit forståelsesramme for rådgivningsforløbet for både rådgivere og klienter. Men hvor de fleste klienter ved rådgivningsforløbets begyndelse opfatter det som et individuelt projekt, der tager udgangspunkt i en personlig gentest, bliver risikokortlægningen af rådgiverne anskuet som et projekt, der vedrører og involverer hele den genetiske familie. For rådgiveren er det slægtshistorien, som den nedfældes på stamtraet - og ikke en gentest - der er det primære redskab til at vurdere en sygdomsrisiko.

Stamtræet bliver også ramme for fortællingens tidslige kategorier: fortid, nutid og fremtid. Stamtrxet skal sammen med journaler danne baggrund for rådgiverens mulighed for at forstå genets rejse i tid og rum. Rådgiverne anser ikke sygdomstilfælde som isolerede begivenheder, men som hændelser, der er relateret til hinanden, og med genet som mellemled, bliver årsag til hinanden. For rådgiverne drejer det sig om at finde ud af, hvor sygdom stammer fra, hvilket handler om at finde vejen, ad hvilken genet har rejst. Omtalen af gener som subjekter, der 'rejser', 'vandrer' og er 'ansvarlige for sygdom' samt den nærmest detektiviske afdækkelse af dets 'rejse' gennem generationer lægger op til en forståelse af gener som skabere af sygdoms- og slægtshistorie. Herved synliggør stamtræet en specifik og kulturelt betinget tidsforståelse, hvor tid kommer oppefra og bevæger sig nedad, og hvor liv følger tid, således at identitet overføres fra forældre til børn (Strathern 1992a, 62 \& 52). Denne lineære tidsforståelse indeholder også en forståelse af, at årsager så som genetiske disponeringer flyder irreversibelt nedad (se ibid, 72).

Stamtræet kan anskues som en særlig relationsmodel (Bouquet 1996, 56). Stamtrxet definerer biologiske relationer mellem konkrete personer og fremstiller derved enkelt personer som indbyrdes forbundne og som tilhørende en fælles enhed - en slægt. Slægten er for rådgiveren ikke en tilfældig gruppe personer, men en gruppe personer som er genetisk og derfor kropsligt forbundet. Stamtræets effektfulde visualisering af familien som et biogenetisk fællesskab indeholder en forestilling om en kropslig forbundethed mellem individ og slægt. Det genetiske perspektiv på sygdom understreger slægtens biologiske fundament og definerer en konstituerende relation mellem krop og slægt. Dette er en kropsforståelse, som jeg betegner 'fællesskabskroppen'. Denne kropsforståelse får stor betydning i rådgivningssammenhæng, hvor involvering af andre slægtninge både diskuteres i forhold til udredning af risiko og i forhold til informering om en arvelig betinget risiko. Da genetikken betragter slægten, snarere end det enkelte individ, som patienten (Finkler 2000, 50), bliver stamtræet et billede på, hvem patienten er, det vil sige, hvem risikoen for sygdom angår. Stamtræet leverer kortet over, hvem der skal informeres, og forestillingen om slægten som et fællesskab gør det nærliggende at pålægge den enkelte klient ansvaret for opgaven, da denne har pligter over for fællesskabet.

Stamtræet illustrerer fortællingens grundstruktur som en bevægelse fra sygdom i fortiden (de ældste generationer) til nuets kortlægning af nulevende personers risiko (de midterste og nederste generationer), som udgangspunkt for kampen for og håbet om, at ingen $\mathrm{i}$ fremtiden må opleve livstruende sygdom (de midterste og nederste generationer). Dette er rådgivningens dominerende fortælling, som er analog med fællesskabskroppen, da kampen mod sygdom netop ikke i første omgang angår det enkelte individs krop, men alle slægtens kroppe.

Som nævnt opfatter klienterne i udgangspunktet risikovurderingen som et individuelt projekt, der angår egen krop, og som andres kroppe og liv ikke skal involveres i. Denne opfattelse viser en anden relationsmodel, hvor krop konstituerer selv og 
ikke nødvendigvis en forbundethed med andre kroppe. Denne kropsforståelse kalder jeg den 'autonome personlige krop'. Den løbende fortolkning af betydningen af slægtskab, som finder sted i samtalen mellem klient og rådgiver, vil i det følgende diskuteres som et møde mellem fællesskabskroppen og den autonome personlige krop.

\section{ER GENER FAMILIENS ELLER INDIVIDETS?}

\section{Heidi: sporgsmålet om social adgang}

Heidi er 30 år. Hun er ikke selv syg, men har slægtninge på både sin mors og fars side, som har haft brystkræft. På baggrund af stamtrxet vurderer rådgiveren, at der ikke $\mathrm{i}$ hendes familie tegner sig et overbevisende billede af arvelig brystkræft, men at en arvelig betinget risiko for brystkræft heller ikke kan udelukkes. I sin rådgivning får hun at vide, at der er den mulighed for at blive klogere, at hendes faster, som er syg af kræft, lader sig genteste. ${ }^{7}$ Heidi er meget interesseret $i$, at denne gentest bliver lavet, men føler sig usikker på at skulle spørge sin syge faster om den blodprøve, der er næste skridt for, at gentesten kan foretages. Hun oplever det som et problem, at hun ikke har et nært forhold til sin faster, og at hun ikke på nogen måde har taget del $\mathrm{i}$ dennes sygdomsforløb. Yderligere finder hun det problematisk, at fasteren måske ikke lever, når testsvaret foreligger. Rådgiveren svarer hende: "Det man skal indse, er, at din faster gør det (bliver gentestet) for sine slægtninges skyld. Hun får sådan set sandsynligvis ikke ret meget ud af det selv. Hvis hun skal gøre det, skal hun gøre det for sin datter og sin søsters skyld". Heidi siger, at hun gerne vil tale med en anden faster, som hun er tættere knyttet til, om muligheden for, at den syge faster afgiver blodprøve, men føler samtidig, at det er forkert at tage den syge fasters eventuelle blodprøve op med en anden i familien. Rådgiveren forstår ikke helt, at Heidi anser det for et problem at tale med sin raske faster om det, før hun går til den syge. Rådgiveren siger, at det er familien, det handler om og fortsætter 'lidt simpelt sagt, er det sådan, at der er nogle som investerer mere end andre, og nogle som høster mere end andre'. Heidi ender med at sige, at hun vil tage kontakt til sin syge faster, fortælle om muligheden for gentest og pointere, at fasteren skal gøre, som hun finder bedst. Rådgiveren svarer, at klinikken ikke har en forskningsmæssig interesse i blodprøven, og at familien kun skal få foretaget gentesten, hvis de ønsker det.

Heidis usikkerhed og tøven over for at kontakte fasteren afslører tre etiske problemstillinger: 1) at hun skal bede en genetisk nær, men socialt perifer, slægtning om en blodprøve, 2) at den der afgiver blodprøve ikke nødvendigvis făr glæde af resultatet, og 3) at det føles forkert at diskutere en slægtnings mulige test med en anden slægtning.

Mange andre, jeg har interviewet, giver udtryk for, at sygdomsoplysninger og viden om en genetisk betinget sygdomsrisiko ikke er neutrale emner, men forbundet med personlige erfaringer af sygdom og død. Det er således et emne, som både opleves som dybt eksistentielt og sårbart og som meget personligt. Heidis tøven udtrykker, hvad Susanne Lundin $(1999,7)$ refererer til som en stærk fornemmelse af kropslig integritet og afgrænsethed. Denne forståelse af kroppen er et eksempel på den personlige autonome krop, ifølge hvilken fasterens blod og den genetiske viden, som dette blod kan afdække, er fasterens og dermed ikke noget, som Heidi kan gøre krav på. At skulle bede om noget så personligt føles som at overtræde en grænse.

Rådgiveren derimod giver udtryk for en forståelse af kroppen som forbundet med andre slægtninges kroppe. Hun pointerer, at "det er familien, det drejer sig om", og at familien skal træffe beslutningen, hvormed hun "plotter" fortællingen om genetisk risikoudredning som et projekt for den genetiske familie. I en analyse af relationen mellem individuelle og kollektive narrativer 
i bevægelsen Anonyme Alkoholikere, viser Vibeke Steffen, at fortællerens personlige sorg og smerte mister sin meningsløshed, idet den ved at blive fortalt bliver til en kollektiv fælles viden (Steffen 1997, 106). Rådgiveren lægger op til en lignende proces, idet hun fremfører, at fasteren kan lade sig teste for andre slægtninges skyld. I tilvejebringelsen af en fælles genetisk viden, transformeres den enkeltes personlige sygdomserfaring og smerte til en kollektiv værdi, der kommer nutidige og fremtidige raske slægtninge til gode, idet viden om genetisk risiko giver mulighed for kontrolundersøgelser. Hospitalsjournalen eller blodprøven bliver en gave til andre slægtninge. Samtidig skaber rådgiveren med sin markedsmetafor ('nogle investerer mere end andre, nogle høster mere end andre') en forbindelse mellem markedet og familien mellem to forskellige erfaringsverdener for at få Heidi til at anskue de ulige vilkår, hvad angår indsats og gevinst. Pointen synes at være, at bidrager man til udredningsprocessen med sin egen hospitalsjournal eller sit eget blod som indsats, hjxlper man andre til at høste en gevinst. Denne dobbeltmetaforik, hvor blodprøven både forbindes med markedsfeltet ( $\mathrm{k} ø \mathrm{~b}$ og salg) og med gaveudveksling (typisk for familierelationer) udtrykker en flertydighed om adgangen til delt substans, som meget vel kan hænge sammen med, at spørgsmålet om, hvorvidt blodprøven skal forstås som en gave eller en vare, er vanskeligt og ikke afføder et klart svar hos hverken rådgiver eller klient. Dobbeltmetaforikken er måske en måde at søge efter den rette ramme for plottet om risikovurdering som et projekt for den genetiske familie. Dette vidner også om, at tale (her metaforisk tale) bliver en måde at opdage og behandle verden på (Hastrup 2000, 8), og at betydning derfor hele tiden er under tilblivelse i interaktionen.

Uanset om fasterens blodprøve skal opfattes som en gave eller som en vare, er det rådgiverens holdning, at Heidi kan bede om blodprøven. Dette hænger sammen med, at gener begrebsliggøres i deres egenskab af at skabe forbundethed, hvilket fæellesskabskroppen udtrykker. Fra dette perspektiv tilhører en gentest ikke det enkelte individ, men den genetiske familie. Implicit i dette perspektiv er en forståelse af, at genetiske relationer i sig selv skaber sociale forpligtelser og legitimerer adgang til andre slægtninges kroppe og liv. Denne opfattelse af familien som et genetisk og socialt fællesskab er ikke grebet ud af den blå luft, men korresponderer med den tidligere nævnte euro-amerikanske opfattelse af, at det sociale (forpligtende familierelationer) bygger på det naturlige (biologiske relationer) (Strathern $1992 \mathrm{a}+\mathrm{b})$. Rådgiveren udfordrer Heidis forståelse af kroppen som tilhørende den enkelte og åbner op for en forståelse af kroppen som forbundet med andre kroppe i en meget konkret forstand.

Disse andre kroppe er i brystkræft-rådgivninger, som Heidis, kvindekroppe. På trods af, at Heidis far er en mulig viderebringer af en genmutation, ${ }^{8}$ får han ikke nogen rolle i risiko-udredningen. Fokus i samtalen er andre kvindelige slægtninge og deres sygdoms- eller risikosituation. På denne måde er risikoudredningen med til at definere en kønnet forbundethed mellem kvindelige slægtninge, som også i nogle familier er med til at skabe en oplevelse af et skæbnefællesskab.

Samtalen mellem Heidi og rådgiveren er lige som mange andre rådgivningssamtaler, jeg har været med til, en situation, hvor to kropsbilleder mødes: den autonome personlige krop og fæellesskabskroppen. Disse kropsbilleder kan analytisk begrebsliggøres som forskellige relationsmodeller, der vedrører relationen mellem gener, krop og individ(er). Hvor den autonome personlige krop definerer en konstituerende relation mellem gener, krop og selv, understreger fællesskabskroppen en konstituerende relation mellem gener, krop og slægt. Disse kropsbilleder indeholder derfor også forskellige forståelser af forholdet mellem på 
den ene side genetiske forbindelser og på den anden side sociale forpligtelser og sociale muligheder. Kropsbillederne angår forståelser af intersubjektivitet. Samtalen om kropslige grænser er også en samtale om sociale grænser. I denne samtale bliver grænsen mellem, hvad der opfattes som personligt, og hvad der opfattes som familiært, udfordret og forhandlet. Denne forhandling indebærer moralske overvejelser over, hvad man kan kræve fra genetiske slægtninge, hvad man kan forvente af dem, og hvad man kan dele med dem.

Heidis tøven viser, at en genetisk relation ikke opleves at være tilstrækkelig til at føle en legitim adgang til en anden slægtnings verden, på trods af at blodprøven tænkes som en hjælp til at få en viden, der sigter på at forebygge sygdom. Hendes tøven udtrykker, at der i praksis finder et valg sted med hensyn til hvilke slægtninge uden for kernefamilien, man betragter som familie, og at genetisk nærhed ikke automatisk skaber social nærhed. De valg 9 der gøres med hensyn til, hvem man har kontakt med, tegner et billede af slægtskab, som refererer til den umiddelbare erfaring og følelse af at være beslægtet. Heidis raske faster er en del af dette slægtskab i modsætning til den syge. På baggrund af et engelsk materiale om slægtskabsforståelser hævder Jeanette Edwards, at det biologiske og det sociale er gensidig nødvendige (Edwards 1999, 318). Ligeså peger mit materiale på en afhængighed mellem og derfor samtidig tilstedeværelse af det biologiske og det sociale, hvis man skal kunne føle adgang til en anden slægtning. Denne samtidige tilstedeværelse af det biologiske og det sociale skaber 'erfaret slægtskab' og indebærer, at man for eksempel kan opleve at have social adgang til det, der opfattes som intimt og privat i en andens liv. Lisbeth Sachs (1998, 78-81) studie af svenske kvinder, som gennemgår genetisk rådgivning og testning viser på tilsvarende vis, at det biogenetiske perspektiv på slægt ikke stemmer overens med kvindernes egne forståelser af nærhed og distan- ce. Rådgivningsprocessen eksponerer de sociale valg, som er gjort med hensyn til, hvem man føler sig i familie med.

At spørge om en kropslig substans (blod) fra en person, som man er knyttet til genetisk men ikke socialt, opleves af stort set alle, jeg har fulgt i rådgivningsklinikkerne, som at overskride en integritetsgrænse og gøre vold på etablerede normer for, hvad man kan tillade sig. Frllesskabskroppen accepteres ikke uden videre. På den anden side er der ikke nogen vej til genetisk risikovurdering uden om slægtninge.

\section{Adam: spørgsmålet om ansvar}

Adam er 48 år og har haft tyktarmskræft flere gange. Det samlede billede af sygdomstilfælde i hans familie peger på en arveligt betinget risiko, og Adam får i forbindelse med sin rådgivningssamtale taget en blodprøve, som skal analyseres med henblik på at finde den genmutation, som rådgiveren identificerer som årsag til hans egne og andre slægtninges kræfttilfælde. Efter en dialog om hans egen situation, kommer samtalen til at dreje sig om informering af andre slægtninge. Adam fortæller, at flere af hans mors søskende har haft kræft. Rådgiveren siger, at disse slægtninges efterkommere også er i risiko og fremhæver, at et eventuelt fund af genmutation hos Adam vil gøre det muligt at tilbyde dem gentest. Adam fortæller, at denne del af familien er emigreret til Canada, og at han ikke kender dem eller har kontakt med dem. Med et blik på stamtræet sige han 'men jeg må jo have et væld af fretre og kusiner'. Rådgiveren svarer: 'Jeg vil ikke presse dig, men jeg vil være interesseret $i$ at få oplysninger om dine morbrødre og mostre. Hvis der er noget, vi kan gøre - og det er der da - så burde dine fretre og kusiner få besked'. Adam fortæller, at hans håb er, at et eventuelt fund af genmutation vil overbevise hans lillebror om, at det ikke er så tilfældigt, som hans læge siger. Emnet forlades, men sidst i samtalen vender rådgiveren tilbage til spørgsmålet om de canadiske slægtninge og 
siger, at Adams moster Esther må kunne tænkes at have oplysninger om de canadiske slægtninge. Adam giver hende ret i, at Esther er eneste forbindelsesled til Canada, og han accepterer at forsøge at kontakte hende.

Rådgiveren udtrykker i samtalen med Adam et ønske om en effektiv og omfattende informering af Adams slægtninge ud fra en betragtning om, at viden skaber et ansvar til at informere om risiko og forsøge at redde andre slægtninges liv. Hun ønsker tillige at undgå, at Adam senere skal få samvittighedskvaler, hvis ikke-informerede slægtninge bliver syge. Plottet om genetisk udredning som et projekt for den genetiske familie knyttes til det overordnede plot om sygdomsforebyggelse. Adam får en mission, i hvilken kampen mod kræft ikke kun angår hans egne brødre, men hele den genetiske familie og dermed også ukendte slægtninge i Canada. En fortælling bliver lagt for hans fødder, hvor han er hovedpersonen, der tager en stor udfordring op (at opspore ukendte slægtninge), overvinder de svære situationer og problemer, som måtte opstå (f.eks. at kontakte Esther, som han ikke har set i mange år og at opsøge myndigheder i Canada) og udfører en heltegerning (redder menneskeliv). Rådgiveren får ham til at acceptere denne mission ved blandt andet at pointere andre slægtninges udbytte af risikoviden og ved at identificere, hvem han kan få oplysningerne fra.

Rådgivningens konkretisering af risiko som noget, man kan følge på stamtræet ud i forskellige grene af familien, er, mener jeg, med til at transformere risikoen fra at være et abstrakt sandsynlighedsforhold til at blive en konkret og nærværende realitet, hvis rejse kan spores på stamtræet (oppefra og ned) til Adam og til ukendte slægtninge i Canada. I denne tingsliggørelse ${ }^{10}$ af risikoen ligger en opfattelse af risiko som lokaliseret i den enkelte og som definerende den enkeltes helbred. Genmutation henviser til risiko, som henviser til sygdom, som så vidt muligt bør forebygges. Yderligere spores i tingsliggørelsen af den genetiske risiko en udbredt opfattelse af gener som konstituerende individualitet og dermed som selvets kerne og kode (Nelkin \& Lindee 1995, 2). Men tingsliggørelsen af den genetiske risiko - som er analog med billedet af den autonome krop - definerer ikke kun individuelle kroppe, men også en konkret forbundethed med andre. De canadiske slægtninges risiko bliver, netop i kraft af at være direkte forbundet med Adams risiko, tilført betydning som et anliggende for Adam. På baggrund af den biologiske kendsgerning, som genmutationen defineres som, italesættes et ansvar for andre slægtninges helbred.

Samtalen mellem rådgiveren og Adam kan ses som en forhandling af hvilke plot, der skal strukturere fortællingen, hvilket samtidig bliver en forhandling af fortællingens mål og dens aktører. Rådgiverens sygdomsforebyggende plot samtænkes med fællesskabskroppen, ifølge hvilken den genetiske forbundethed definerer fortællingens aktører og på den måde bliver udgangspunkt for Adams indsats for at redde en række canadiske slægtninge fra en livstruende sygdom (fortællingens ideelle slutning).

Det plot, som strukturerer Adams fortælling, tager udgangspunkt i de nære sociale relationer til blandt andet hans bror, overfor hvem han føler det ansvar, som rådgiveren prøver at få ham til at føle over for ukendte slægtninge i Canada. Her er det netop erfaret slægtskab (samtidigheden af det biologiske og det sociale), der definerer fortællingens personer. Mine observationer af rådgivningssamtaler viser, at rådgiverne udmærket forstår klienternes oplevelse af, at det er sammenfaldet af det sociale og det biologiske, som definerer 'rigtige slægtninge'. Ligeså er klienterne enige i rådgivernes syn på, at biologien definerer slægtskab. Men de to parter har forskellige interesser og opgaver $\mathrm{i}$ fortællingerne og plotter dem derfor forskelligt. Udgangen på Adams rådgivning er derfor ikke et klart svar på spørgsmålet om de canadiske slægt- 
ninge. Selvom Adam indvilger i at forsøge at kontakte Esther, virker han ikke overbevist om projektet. Snarere lægger forhandlingen af plottet op til en refleksion over forbindelsen mellem genetisk slægtskab og socialt tilhørsforhold. Hører Adam sammen med de ukendte slægtninge i Canada? Hvis der er tale om et tilhørsforhold, forpligter dette til informering om en genetisk betinget risiko for kræft? Tilhørsforhold såvel som personlig (sygdoms)identitet er i rådgiverens perspektiv forhold, som overføres gennem genetiske relationer i det fællesskab, som biologien definerer, og som de kalder familie. Men Adam lægger vægt på, at tilhørsforhold og ansvarsfølelser i langt højere grad bygger på et erfaret fællesskab. Hans modstand mod rollen som kontaktperson til familien er også en kønnet reaktion. En række eksempler i dette studie viser, at mænd i langt mindre grad end kvinder føler et personligt ansvar for andre slægtninges helbred og ikke frivilligt påtager sig rollen som kontaktperson. Dette understreger, at det er kvinder, som agerer i slægtskabsfeltet, hvilket også andre studier peger på (cf. di Leonardo 1987).

\section{DET SLÆGTSBUNDNE MENNESKE}

I en analyse af tilhørsforhold i England viser Edwards og Strathern, at krav rejser via forbindelseskxder, og at krav ikke kun rejser i én retning (Edwards \& Strathern 2000, 149 \&152). I den fortælling, som rådgiverne foreslår, hvor der skabes en klar forbindelses- og årsagskæde, synes de fælles gener (som skaber kæden) at stille krav: Krav om at en slægtning afgiver sygdomsoplysninger eller blodprøve og krav om at blive informeret, hvis en anden i slægten har en genetisk viden. Samtidig italesættes gener også - af både rådgivere og klienter som tilhørende den enkelte og som lokaliseret $\mathrm{i}$ individet, hvilket billedet af den autonome krop er udtryk for. Gener defineres således både som skabere af relationer og af personlige identiteter. Dette baner i rådgiv- ningsrummet vejen for en forståelse af kroppen som konstituerende den enkeltes autonomi samtidig med, at den er forbundet med andre genetiske kroppe fysisk og socialt. Både den autonome krop og fællesskabskroppen er imidlertid udtryk for, at biologiske facts i denne del af verden tænkes som fundament for sociale facts såsom individualitet og omsorgs/ansvarsrelationer. Med udgangspunkt i biologiske facts bliver rådgivningerne et socialt rum, hvor betydningen af det individuelle og det frlles forhandles.

Samtidig med at klienterne forstår rådgivernes perspektiv, da det netop bygger på udbredte kulturelt forankrede forståelser af slægtskab, fører dette perspektiv til ambivalente følelser om adgangen til og ansvaret for slægtninge. Narrative strukturer organiserer erfaring og tilfører erfaring betydning, men der er altid følelser og erfaringer, som ikke kan omfattes af den dominerende fortælling (Bruner 1986, 143). Den dominerende fortælling om fællesskabskroppen kan, som rådgivningssamtalerne viser, ikke omfatte den sociale erfaring af at være relateret biologisk, men ikke socialt. Diskrepansen mellem stamtræets kortlægning af slægtsrelationer og de pågxldendes egne erfaringer af slægtskab tydeliggør, at det sociale ikke vokser naturligt ud af det biologiske, men at der hele tiden finder valg sted. Disse valg afdækker fortællinger om erfaret slægtskab, hvor det ikke nødvendigvis er fælles gener, som afgør, hvem der er med i fortællingen, og hvor fælles gener ikke automatisk stiller krav om intimitet, ansvar eller tilhørsforhold. Heidi og Adams overvejelser viser yderligere, at den 'sociale del' af erfaret slægtskab er mangesidig. Det sociale, som det synliggøres i disse dialoger, handler for eksempel om kønnede ansvarsrelationer, om tilhørsforhold, om nærhed og distance, om gavegivning og om betydningen af at dele tid og rum. Og det er de forskellige måder, som disse forhold relaterer sig til hinanden på, som udmønter sig i forskellige erfaringer af forbundethed og 
slægtskab mellem mennesker. Fordi klienter som Heidi og Adam tænker genetisk risikovurdering i forhold til andre former for forbundethed, nås der ikke i dialogen med rådgiveren entydige moralske svar eller sociale løsninger på spørgsmålene om, hvad fælles gener betyder for sociale relationer og identitet, og hvilke konsekvenser den genetiske risikoviden har for fremtidige handlinger over for slægtninge. Ligesom studierne af mødet med forplantningsteknologien (cf. Franklin 1997, TjørnhøjThomsen 1999) viser dette studie, at involveringen med genteknologien ekspliciterer kulturelle forståelser af slægtskab ved blandt andet at synliggøre slægtskab som frembragt af sociale valg. På én og samme tid er risikokortlægningen med til at de-naturalisere genetisk slægtskab og understrege genetisk slægtskab som naturlige facts. Dette dobbeltperspektiv fremtvinger hos de involverede en refleksion over og en redefinition af, hvad der tæller som slægtskab, og hvilken betydning det har. Mine mange interviews med personer som Heidi og Adam viser, at disse menneskers søgen efter svar efter at definere fortællingens plot - fortsætter i handlinger mellem slægtninge såvel som i samtaler med antropologen. Men på trods af, at der foregår en dialogisk forhandling og skabelse af betydning om slægtskab (og dermed om relationen mellem individ og fællesskab), er det tydeligt, at selve risikoudredningsmetoden og stamtrxets centrale position i denne strukturerer fortællingen. Fællesskabskroppen som styrende for fortællingen vidner om, at narrativer ikke kun er betydningsstrukturer, men også magtstrukturer (Bruner 1986, 144), der i dette tilfælde definerer bestemte måder at handle på $\mathrm{i}$ forhold til slægtninge. Udlægningen af den genetiske familie som en fællesskabskrop understøttes af en rådgivningspraksis, hvor vejen til genetisk risikovurdering ufravigeligt involverer genetiske slægtninge. Det betyder, at det genetiske perspektivs handlingsrationale får sociale konsekvenser, der kan karakteriseres som en genetificeringll af sociale relationer. Heidi kontakter for eksempel sin syge faster for at bede hende om en blodprøve, og fasteren svarer, at hun vil mødes personligt med Heidi for at diskutere spørgsmålet om gentest. Adam forsøger via en anden slægtning at finde frem til Esther, hvilket i sidste ende ikke lykkes for ham. Rådgivningens praksis danner som i disse tilfælde grundlag for at kontakte slægtninge, og ofte bliver risikoudredningsprojektet eller en allerede identificeret sygdomsrisiko et fælles projekt for de involverede. Viden om genetiske sygdomsrisici former både personlige identiteter, kønnede slægtsfællesskaber og erfaringer af familiemæssige tilhørsforhold.

\section{Noter}

1. Man mener i dag, at mellem 5 og 10 procent af alle tilfælde af tarm- og brystkræft skyldes genændringer. Dette gør disse sygdomme til nogle af de hyppigst arvelige sygdomme overhovedet. Samtidig må det påpeges, at langt de fleste tilfælde af tarm- og brystcancer (mindst 90 procent) ikke er genetisk betingede. At det genetiske perspektiv på kræft i offentligheden har fået en så stor opmærksomhed kan således synes overdrevent. Både den store opmærksomhed på genetiske årsagsforklaringer og de høje forventninger til genetikken, som af nogle forskere betegnes som illusoriske (Holzman \& Marteau 2000), kan anskues som udtryk for en genetificering af sygdomsbegrebet og i bredere forstand af lægevidenskaben (Koch 1999 og 2001). 2. At slægtshistorien er rådgiverens primære redskab til at vurdere en genetisk betinget sygdomsrisiko, hænger sammen med, at en arvelig cancerform ikke kan diagnosticeres hos den enkelte, da den klinisk ikke adskiller sig fra ikke-arvelige cancertyper.

3. Baggrunden for artiklen er et antropologisk feltarbejde, i hvilket 25 personer er blevet fulgt gennem et cancergenetisk rådgivningsforløb Jeg har både været til stede ved personernes rådgivningssamtaler og besøgt og interviewet dem i deres hjem, for manges vedkommende 2-3 gange inden for en periode på to år. Feltarbejdet er udført i forbindelse med mit igangværende ph.d.-projekt 'Når gener bliver en risiko. Et studie af personlige og sociale problemstillinger ved at modtage rådgiv-- 
ning i forbindelse med arvelig kræft'. Feltarbejdet er udført i tilknytning til tre cancergenetiske rådgivninger i Danmark.

Ph.d.-projektet indgår i et tværvidenskabeligt forskningsprojekt 'Molekylærgenetisk diagnostik og sygdomsforebyggelse', som ledes af lektor, dr. phil. Lene Koch, Panum Instituttet, og finansieres af Statens sundhedsvidenskabelige forskningsråd. 4. I mangel af bedre betegnelser bruger jeg ordet 'klient' for personen, som søger rådgivning. Det synes misvisende at kalde dem patienter, da langt de fleste af disse personer aldrig har været syge af kræft og ikke ønsker at opfatte sig selv som syge. 5. I en dansk kontekst er begrebet dialogisk fortælling blandt andet brugt som analytisk perspektiv på kliniske interaktioner af Hanne Jessen Busch (1997). 6. Patricia Kaufert hævder, at populationsscreeninger (særlig bryst- og underlivs-screeninger) i høj grad har været med til at skabe et billede af en bedragerisk kvindekrop, som føles rask, men er kræftsyg, og hvor overlevelse afhænger af tidlig opsporing (Kaufert 2000, 170). Dette billede af kræft, som noget man ikke direkte kan mærke - før det er for sent - og som derfor skal opspores ved hjælp af teknologi og bekæmpes på et tidligt stadium, ligger til grund for både rådgivere og klienters understregning af kontrolundersøgelser som et naturligt redskab til at undgå livstruende sygdom.

7. Såfremt klienten ønsker gentest, beder rådgiverne altid om en blodprøve fra en person, som har været/er syg, da dette skaber størst sandsynlighed for at identificere det arveanlæg (en genmutation), som menes at være årsag til kræft i en familie. I ca. halvdelen af de familier, hvor stamtræet med sikkerhed indikerer arvelig bryst- eller tarmkræft, identificeres ved genmutationsundersøgelse et arveanlæg. Alle genetiske slægtninge kan i så fald gentestes for lige netop dette anlæg, som giver 8090 procents risiko for at udvikle kræft. I de mange genmutationsundersøgelser i familier med enten sikker eller usikker diagnose, hvor der ikke findes et arveanlæg, kan arvelig kræft ikke udelukkes.

Rådgiverne mener snarere, at der er tale om arveanlæg, som det ikke er muligt at identificere med den eksisterende viden og teknologi. I så fald bliver stamtræet alene udgangspunkt for risikovurdering og tilbud om kontrolundersøgelser.

8. Mænd får i sjældne tilfælde brystkræft, men risikoen betragtes ikke som stor og giver ikke anledning til f.eks. kontrolundersøgelser.

9. Med valg tænkes på sociale handlinger, som altid foregår i relation til andre og inden for en social kontekst. Valg associerer ofte en forestilling om et autonomt uafhængigt individ, som træffer beslutninger i et værdifrit univers og uden for sociale relationer. Denne forestilling om individet ligger ikke til grund for min omtale af valg.

10. Flere studier peger på, at risiko som et statistisk begreb bliver tingsliggjort i kliniske og politiske sammenhænge (Gifford 1986, Douglas 1994, Adelswärd \& Sachs 1996).

11. Se Koch (2001) for en nærmere diskussion af genetificeringsprocessen.

\section{LITTERATURLISTE}

• Adelswärd, V. \& Sachs, L (1996): "The Meaning of 6.8: Numeracy and Normality" i Health Information Talks", i Social Science and Medicine 43/8. - Bruner, Edward (1986): "Ethnography as narrative", i Edward Bruner \& Victor Turner (eds.): The anthropology of experience. University of Illinois Press, Urbana.

- Bouquet, M. (1996): Family trees and their affinities: "The visual imperative of the genealogical diagram", i J. Roy. anthrop. Inst. (N.S) 2:43-66. - Busch, Hanne. J. (1997): "En dialogisk fortælling om diagnose og død", i Helle P. Hansen \& Pia Ramhøj (eds.): Tvervidenskabelige perspektiver på sundhed og sygdom. Akademisk forlag, København.

. Carsten, Janet (2000): "Introduction: cultures of relatedness", i Janet Carsten (ed.): Cultures of Relatedness. New Approaches to the Study of Kinship. Cambridge, Cambridge University Press.

- di Leonardo, Michaela (1987): "The female world of cards and holidays: women, families, and the work of kinship", i Signs 12 (3): 440-53.

- Douglas, Mary (1994): Risk and Blame. Essays in Cultural Theory. Routledge, London.

- Edwards, Jeanette (1999): "Why Dolly Matters: Kinship, Culture and Cloning”, i Ethnos 64/3. - Edwards, Jeanette \& Strathern, Marilyn (2000): "Including our own", i Janet Carsten (ed.): Cultures of Relatedness. New approaches to the study of kinship. Cambridge University Press, Cambridge. - Finkler, Kaja (2000): Experiencing the new genetics. Family and kinship in the medical frontier. University of Pennesylvania Press, Philadelphia. - Franklin, Sarah (1997): Embodied Progress. A cultural account of assisted conception. London, Routledge.

- Gifford, Sandra M. (1986): "The meaning of lumps: A case study of the ambiguities of risk", i Craig R. Janes, Ron Stall \& Sandra M. Gifford (eds.): Anthropology and Epidemiology. Interdisciplinary Approaches to the Study of Health and Disease. Reidel Publishing Company, Dordrecht. 
· Hastrup, Kirsten (2000): "Menneskelig handling. Illusionen som et dramatisk grundvilkår", i Tidsskriftet Antropologi 41.

- Holzman, Neil A. Holtzman \& Marteau, Theresa (2000): "Will genetics revolutionize medicine?", i New England Journal of Medicine 343 (2):141-

144 .

- Koch, Lene (1999): "Predictive genetic medicine - a new concept of disease", i Elisabeth Hildt \& Sigrid Graumann (eds.): Genetics in human reproduction. Aldershot, Ashgate.

- Koch, Lene (2001): "Styring af genetisk risikoviden", i Distinktion 3.

- Kaufert, Patricia (2000): "Screening and the body: The pap smear and the mammogram", i Margaret Lock, Allan Young \& Alberto Cambrosio (eds.): Living and working with the new medical technologies. Cambridge University Press, Cambridge.

· Lundin, Susanne (1999): “The Boundless Body: Cultural Perspectives of Xenotransplantation”, i Ethnos 64/1.

- Mattingly, Cheryl (1998): Healing Dramas and Clinical Plots. The Narrative Structure of Experience. Cambridge University Press, Cambridge. - Nelkin, Dorothy \& Lindee, Susan (1995): The DNA mystique. The gene as a cultural icon. W.H. Freeman and Company, New York.

- Schneider, David (1980 (1968)): American Kinship. A Cultural Account. Chicago, University of Chicago Press.

- Steffen, Vibeke (1997): "Life stories and shared experience", i Soc. Sci. Med 45/1.

- Strathern, Marilyn (1992b): After nature: English kinship in the late twentieth century. Cambridge University Press, Cambridge.
- Strathern, Marilyn (1992b): Reproducing the future. Anthropology, kinship, and the new reproduc-tive technologies. Manchester University Press, Manchester.

- Tjørnhøj-Thomsen, Tine (1999): Tilblivelseshistorier. Barnloshed, slagtskab og forplantningsteknologi $i$ Danmark, ph.d.-afhandling. Institut for Antropologi, København.

\section{SUMMARY}

The empirical focus of this article is cancer genetic counselling in Denmark. It analyses the different notions of genes and kinship that are negotiated between counsellor and counselee in counselling. One notion emphasises a defining relationship between genes, body and kin, according to which the genetic family is perceived as a group of bodily related persons, who share genes and should feel a responsibility for one another's bealth. Another notion emphasises a defining relationship between genes, body and self, according to which blood, genes and illness are private matters not easily exchanged between relatives. These notions are conceptualised as two images of the body, a communal body and an autonomous body, and discussed in relation to cultural perceptions of kinship and social experiences of relatedness.

Mette Nordahl Svendsen, ph.d.stipendiat Institut for Antropologi, KU 